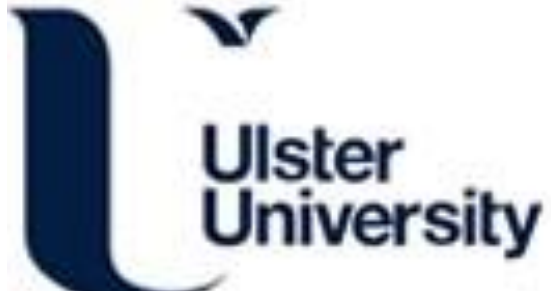

\section{A Fuzzy Cognitive Map method for integrated and participatory water governance and indicators affecting drinking water supplies}

Shahvi, S., Mellander, P-E., Jordan, P., \& Fenton, O. (2021). A Fuzzy Cognitive Map method for integrated and participatory water governance and indicators affecting drinking water supplies. Science of the Total Environment, 750, [142193]. https://doi.org/10.1016/j.scitotenv.2020.142193

Link to publication record in Ulster University Research Portal

\section{Published in:}

Science of the Total Environment

Publication Status:

Published (in print/issue): 01/01/2021

DOI:

10.1016/j.scitotenv.2020.142193

\section{Document Version}

Publisher's PDF, also known as Version of record

\section{General rights}

Copyright for the publications made accessible via Ulster University's Research Portal is retained by the author(s) and / or other copyright owners and it is a condition of accessing these publications that users recognise and abide by the legal requirements associated with these rights.

\section{Take down policy}

The Research Portal is Ulster University's institutional repository that provides access to Ulster's research outputs. Every effort has been made to ensure that content in the Research Portal does not infringe any person's rights, or applicable UK laws. If you discover content in the Research Portal that you believe breaches copyright or violates any law, please contact pure-support@ulster.ac.uk. 


\title{
A Fuzzy Cognitive Map method for integrated and participatory water governance and indicators affecting drinking water supplies
}

\author{
S. Shahvi ${ }^{\text {a }}$, P.-E. Mellander ${ }^{\text {a }}$, P. Jordan ${ }^{\mathrm{b}}$, O. Fenton ${ }^{\mathrm{a}, *}$ \\ a Teagasc, Johnstown Castle, Environmental Research Centre, Co. Wexford, Ireland \\ ${ }^{\mathrm{b}}$ Ulster University, School of Geography and Environmental Sciences, Coleraine, UK
}

\section{H I G H L I G H T S}

- Pathways to good drinking water quality in agricultural areas involve many actors.

- Exploratory network analysis of stakeholders' knowledge and perception was conducted.

- Hierarchy Index examined stakeholder's view on hierarchical or democratic structure.

- Scenario testing highlighted pathways to good agriculture and environmental outcomes.

- The methodology presented is parsimonious and globally relevant in similar subjects.

\section{A R T I C L E I N F O}

\section{Article history:}

Received 28 April 2020

Received in revised form 6 August 2020

Accepted 2 September 2020

Available online 7 September 2020

Editor: Nicoleta Suciu

\section{Keywords:}

Agriculture

Water governance

Water quality

Fuzzy Cognitive Map

Policy
G R A P H I C A L A B S T R A C T

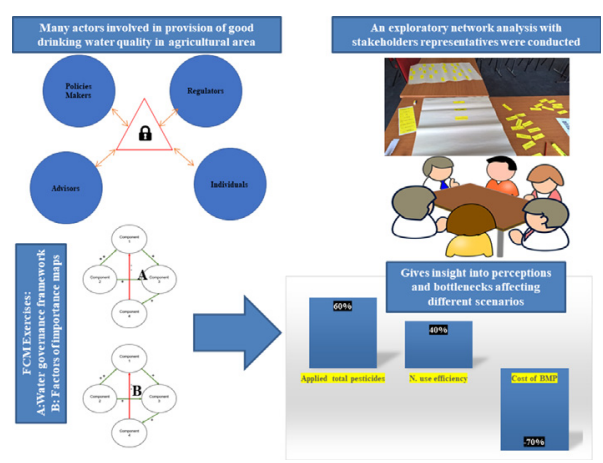

\begin{abstract}
A B S T R A C T
Drinking water governance is challenging with different perceptions and priorities among stakeholders in different countries. To make provision for drinking water protection in agricultural areas, governance systems need to be mapped for bottlenecks to be identified and solutions highlighted. To address this a system thinking approach was used in an explanatory network analysis of Fuzzy Cognitive Maps (FCM) that were created during face to face interviews with stakeholder representative groups (individuals, policy developers, researchers, and regulators). Two exercises were designed and facilitated to obtain stakeholder maps on A) the water governance framework from stakeholders' own perspective with a ranking of actors in terms of their perceived importance and B) a list of importance factors and how these were connected for the provision of good drinking water quality supplies in agricultural areas. Causal relationships were subsequently drawn around each subject allowing mapping. A graph theory Hierarchy Index $(h)$ approach examined if stakeholder groups preferred top down hierarchical governance or a more inclusive democratic governance approach. Finally, an auto-associative neural network method was deployed on group maps for examination during steady-state conditions for three scenarios to be explored i.e. changing "Farmers knowledge", "best management practice (BMP) uptake" and "Farmers behaviour and belief" to the highest level of influence and seeing how the system reacted. Results of Exercise A showed that all stakeholder representative groups had a different perception of the water governance framework. Most stakeholder groups had a democratic point of view regarding water governance structures and the ranking and importance of the actors within the framework. Results of Exercise B demonstrated that most of the groups have similar opinions regarding the highest ranked factors affecting drinking water quality and the possible environmental ecological policy options. In this second exercise, only one representative group showed a democratic outlook whereas all others had a hierarchal outlook. Scenario testing of policy options enabled bottlenecks and possible
\end{abstract}

\footnotetext{
* Corresponding author at: Teagasc, Johnstown Castle, Co. Wexford Y35 Y52, Ireland.

E-mail address: owen.fenton@teagasc.ie (O. Fenton).
} 
solutions to be identified. By boosting "Farmers behaviour and belief" to the highest possible level, resulted in a large increase in other factors - a scenario where farmers could benefit from the outcome. This would be achieved by enhancing farmers' willingness and intention to participate and implement BMPs. Better results would be achieved if farmers believed in the method and could benefit from the outcome. Also keeping "Farmers knowledge" at the highest point had a positive influence on the other factors. This can be achieved by enhancing farmers training and knowledge transfer by local and national actors. This method is widely applicable and should be considered for more integrated and participatory approaches to drinking water governance.

(c) 2020 The Authors. Published by Elsevier B.V. This is an open access article under the CC BY license (http:// creativecommons.org/licenses/by/4.0/).

\section{Introduction}

Water is a finite resource with only one hundredth of $1 \%$ of the world's water readily available for human use. Internationally, drinking water supplies are extracted from surface or groundwater bodies with this percentage varying depending on factors such as climate change, geology, source quality and degradation of aquatic ecosystems (Gundry et al., 2006; Rufener et al., 2010; Daly et al., 2010; Wiek and Larson, 2012). Many external pressures exist in terms of quantity and quality of drinking water supplies including an increasing global population and discharges from industry (Schmoll et al., 2006; Besner et al., 2011; Harisha et al., 2010; Eliasson, 2014). Worldwide, agriculture is a significant sector and itself a pressure on both the quantity and quality of drinking water supplies. The characterization of water abstraction and contamination due to point and diffuse losses of nutrients (e.g. nitrogen and phosphorus, Fenton et al., 2017), pesticides (Morton et al., 2019), pathogens (Ashekuzzaman et al., 2018) and emerging contaminants such as micro-plastics and pharmaceuticals (Lou et al., 2014; Naidu et al., 2016; Machado et al., 2016; Lai et al., 2018) in areas with connectivity to drinking water supplies are subjects of on-going research (McGrory et al., 2017; Khan et al., 2018; Schutz et al., 2019; Panikkar et al., 2019; Jaramillo and O'Shea, 2019). Indeed, research into the provision and implementation of "best management practices" on agricultural landscapes to protect drinking water supplies is an important area of research.

The present study acknowledges that in different countries it is difficult to map the governance structure and assess it from different stakeholders' perspectives. A common goal in all countries within the European Union (EU), for example, is the provision of good drinking water quality. Although all member states are governed by the same EU Directives e.g. Groundwater Directive or Water Framework Directive, each individual state has a varied approach to achieve these directives. It is proposed that this lack of clarity is in itself a "pressure" on the provision of good quality drinking water. For example, in the USA, Lyon (2010) highlighted factors such as the inability to address local water problems on a timely basis, the scattered responsibilities between organisations such as US-EPA and US Geological Survey and confusing water laws. In another example Foster et al. (2016) examined the function of water governance in parts of the UK through a survey of relevant stakeholders. Findings illustrated a good understanding with respect to water governance among stakeholders as a result of sharing and challenging their own knowledge and experience. Additionally, some transformations in water governance are needed to solve complex environmental problems. In Canada, on the other hand, decentralised systems of environmental governance in the form of federal, provisional and municipal frameworks currently predominate. In such a system, water governance is subjected to jurisdictional and scalar fragmentation. According to stakeholders the current water governance model causes some problems including a lack of clarity among authorities and their specific roles, gaps, overlaps, poor data collection and inadequate water quality monitoring (Bakker and Cook, 2011). Therefore, there is still space for further important work to implement improvements that can cascade to a local scale. The present study presents a methodology to achieve this aim, using governance in Ireland as an example.

Progress towards achievement of good drinking water quality in agricultural areas is often constrained by the different perceptions and goals of various stakeholders that affect or deal with the consequences of water regulation. Okumah and Yeboah (2020) found that stakeholders' perceptions and goals for water regulation are influenced by different factors such as water value and pollution sources and concluded that integration of different stakeholder perceptions could improve water governance. Dahik et al. (2018) examined water supply, regulation and management of ecosystems in Paramo, Ecuador. Results showed that stakeholders within a stakeholder representative group and of different groups had substantially different perceptions. Outcomes suggested more interaction among stakeholders and consideration of trades-offs would lead to better convergence of the whole system. In Florida USA, Borisova et al. (2012) through interaction with different representative stakeholder groups developed a watershed implementation plan for the assignation of Total Maximum Daily Loads of pollutants. Outcomes recognized several differences but also commonalities in stakeholder perceptions. The study concluded that finding a common theme across stakeholder groups which have different perceptions, goals, organisational benefits and points of view could potentially highlight solutions to perceived watershed management bottlenecks and problems.

To examine the indicators and factors of importance to provide safe drinking water in agricultural areas, while identifying bottlenecks that hinder such provision, a systems thinking approach is a good option as it can be applied where the system behaviour is affected by the structure of the relationships between variables. Arnold and Wade (2015) defined a "systems thinking approach" as a system which identifies its own goal and then weighs the system elements and the interconnections between these elements. Such an approach has been studied previously to highlight bottlenecks and provide potential solutions. For example, Kabunzana and Simatele (2017) evaluated the causal relationships of an active solid waste management system in the Congo. The study highlighted the importance of systems thinking as an integral framework to understand the complexity of an active solid waste management system. Such an understanding could then facilitate better management of solid waste in a more sustainable, social, and environmental way. Martin et al. (2020) used a systems thinking approach to evaluate the main interactions between natural based solutions and their benefits to investigate the long-term outcomes on various Sustainable Development Goals (SDGs). Results showed that the methodology is capable of demonstrating the complex interconnections among components. Outcomes from the study increased the awareness and motivation for those participating in decision-making or policy-making processes.

There are many participatory modelling approaches that can be used to solve environmental problems. System dynamics models are an example of those models which implement differential equations, to explain a system's reflection to external components and therefore its main application is to model the dynamic manner of ecosystems. System dynamics models require a variety of empirical datasets (which are costly and not always available) to successfully model ecosystems (Ozesmi and Ozesmi, 2004). Suprun et al. (2018), reviewed types of 
participatory modelling approaches developed on system dynamics models. Mediated modelling (MM) is used mainly to model environmental issues. In this approach, stakeholders participate more in the development of the model. Indeed, a high level of commitment from stakeholders along with intensive participation in order to reach an overall agreement over the issue is needed. The Delphi method (DM) in combination with system dynamic modelling has an advantage in situations with limited available data. Stakeholders participate individually and anonymously in the process by replying to questionnaires or online surveys to declare their opinions. Indeed, this technique lets the participants declare their opinions on a topic, while considering the opinions of experts, and then the modeller would have a good knowledge of key issues of the topic. Integrated participatory systems modelling (IPSM) is a novel approach for system dynamic models developed by Suprun et al. (2018). This approach integrates an empirical structural analysis with a series of stakeholder workshops. This approach helps modellers to obtain stakeholders' knowledge, for the system dynamic model and also for the conceptualisation and policyoption testing of the modelling process. The IPSM applies stakeholders' integration at most phases of the model development process. The approach has the advantage of reducing conflict among stakeholders while building trust among them (Suprun et al., 2018).

Some models have been introduced in the literature with the ability to overcome stakeholders' biases by involving them in the experimental design of the methodology. According to Voinnov et al. (2016), some mechanisms are needed to recognize human biases and to solve them in the participatory process. Participants' groups with well-trained facilitators and proper participatory processes would avoid the dominance of perspectives as well as inappropriate individuals' dominance (Voinnov et al., 2016).

Participatory Decision Analysis (PDA) is an approach based on stakeholders' opinions and applies certain tools, such as Multi-Criteria Decision Analysis "to combine the values for a given action and rank the sets of actions" (Voinnov and Bousquet, 2010 p. 3). Participatory Modelling, on the other hand, is focused on stakeholders' engagement and modelling, and would end in decision making. There is the possibility to insert Participatory Modelling in PDA with the advantage that stakeholders can be engaged and trained to learn the experiment and the process, and homogenise values among the stakeholders' representatives. At the beginning of each exercise stakeholders usually have some disagreements on some feature's importance as well as some opposing opinions on the priorities. PM with this design would help with sharing information and building similar views by understanding the system and its design (Voinnov and Bousquet, 2010).

Ulrich and Reynolds (2010) developed the Critical Systems Heuristics (CSH) method, as a reflective framework and set of tools, capable of exploring human perspectives, via questions. The questions test motivation, skills and legitimacy and determine how these are applied to characterize "social roles (i.e. types of stakeholders), specific concerns (i.e. types of stakes), and key issues in a system of interest" (Voinnov et al., 2016 p. 16). Responses to these questions would clarify probable system biases and different perceptions.

A systems thinking approach using the Fuzzy Cognitive Map (FCM) method has been used to interpret the outcomes of many studies as it can be used to address the stakeholders' views on environmental and water quality policy issues (Kafetzis et al., 2010; Papageorgiou and Kontogianni, 2012; Micha et al., 2020). One of the applications of the FCM method is to obtain the perceptions of stakeholders pertaining to a particular subject of interest and help to understand complex systems more efficiently. The importance of including the stakeholders' views in management-decision making has been highlighted elsewhere (Gregory and Keeney, 1994; Berkes, 2004; Lynam et al., 2007; Gray et al., 2012) as well as important efforts by studies to integrate these different views to build system models (Darke and Shanks, 1996; Voinnov and Bousquet, 2010; Cascetta et al., 2015; Juntunen et al., 2018; Chopin et al., 2019). As it is stated in the literature (Biggs et al., 1976; Ozesmi and Ozesmi, 2003; Ozesmi and Ozesmi, 2004) Euler initially used graph theory and has since developed it widely. The first person to use the term "cognitive map" was Tolman (1948) (cited in Ozesmi and Ozesmi, 2003). Later Kosko (1986) developed the FCM approach by means of using the weighted relationships among them in policy modelling projects. Since its development, FCM as an approach has been used as a tool for analysing policymaking, decision-making and social systems. Studies in the last decades have demonstrated that the integration of stakeholders' knowledge in decision-making systems by means of FCM is a proper way to map the governance structure and to solve environmental issues (Axelrod, 1976; Puccia, 1983; Radomski and Goeman, 1996; Kontogianni et al., 2012; Gray et al., 2012). In FCM, the model performance is based on the pre-defined and the additive indicators (variables, factors) and the relationship among them, in terms of strength and the signs of relationships i.e. weights (Ozesmi and Ozesmi, 2003). The variables are either measurable quantities or abstract concepts such as beliefs and knowledge. The additive variables and the strength of the relationship among these variables can be decided by the interviewees. Fuzzy Cognitive Mapping has been already reported in the literature to efficiently solve ecological and environmental issues. Examples include: using FCM to interpret the views of different stakeholders with respect to the Uluabat Lake ecosystem in a study by Ozesmi and Ozesmi (2003); analysing the perceptions of stakeholders regarding two wetlands in Turkey by Dadaser and Özesmi (2001, 2002); and a forest management project in Denmark by Hjortsø (2004). In another example FCM helped to resolve a conflict in the Kizilirmak Delta in Turkey where government and NGOs managed the issue by including the perceptions of the local people and stakeholders (Ozesmi, 1999; Ozesmi and Ozesmi, 2003). Yalçın and Seçme (2001) also used FCM in Turkey to obtain the views of middle and high-level authorities on factors influenced by local industries and found that none considered environment as an influence.

Fuzzy Cognitive Mapping is a flexible tool that has been successfully applied in a wide spectrum of studies such as electrical engineering, political and ecological sciences. Due to its importance in the context of obtaining different perceptions and scenario development, it is entirely proper to apply in decision-making studies (Kok, 2009). One of the advantages of FCM is that it is not a sophisticated and equation-based tool (Ozesmi and Ozesmi, 2004). Moreover, with FCM, it is possible to approach several stakeholders that may have a "diverse knowledge and/ or different degrees of expertise" (Ozesmi and Ozesmi, 2004 p. 3). The technique allows for interaction with separate stakeholder groups and the possibility to aggregate outcomes from individual groups into one FCM. Comparing FCM to other ecological modelling systems such as system dynamics models some of its advantages can be highlighted. System dynamics models implement differential equations, which can explain a systems reflection to external components and therefore is mainly used to model the dynamic manner of ecosystems. Although system dynamics models require a variety of empirical datasets to successfully model ecosystems, FCMs are applicable even when limited data is available. Also, FCMs are participatory approaches where stakeholders cooperate to build the systems whereas in system dynamics models, the stakeholders' interests are gathered to build their views about a system. FCMs are easy-to-build approaches, produce qualitative results and do not require expert knowledge. This was an advantage for the present study as many different stakeholders were contacted and the groups contained people with varied levels of knowledge. The FCM approach implemented in this study was not obtained from empirical data, but modelled perceptions based on stakeholders' views, which is necessary when considering a complex system such as water governance with many stakeholders involved.

However, as stated by Kok (2009) and Cumming et al. (2005) there are some uncertainties and potential inconsistencies in FCM-built scenarios and in the interpretation of the casual relationships between factors in modelled systems. Another drawback is the rather poor methodology to derive the semi-quantification of relationships. Nevertheless, 
this is generally not a major drawback in cases where different groups are involved in the construction of FCMs. Moreover, due to the semiquantitative values of FCM it is not easy to implement common calibration methods and instead the steady-state condition (equilibrium condition of the system) is considered as the calibrated form of these systems (Kok, 2009). Another perceived drawback of FCM is the abnormal fluctuations of weights that sometimes occur in trials to bring the systems into steady-state mode (Groumpus, 2017). When applying FCMs it is not possible to bring in different stakeholders' perceptions and probable bias in the experimental design and this instead should be explained to interviewees.

With these FCM advantages and caveats noted, and taking Ireland as a case study, the objectives of the present study were to a) map the drinking water regulatory framework from different stakeholder perspectives using FCM; b) to examine the indicators and factors of importance to provide safe drinking water in agricultural catchments and; c) bring this information together to identify the regulatory bottlenecks for the protection of drinking water and improve the decision-making and management system for drinking water provision. For these objectives a system thinking approach was designed, stakeholders were identified and approached and then face-to-face interviews were carried out over an extended time period. The focus of the work was on agricultural activities and meso-scale catchments were defined as the management boundary.

\section{Material and methods}

A flowchart summarising different steps of the developed and applied methodology is summarised in Supplementary material (Fig. S1).

\subsection{Stakeholder group exercises}

To obtain FCMs, face to face and in-depth interviews with representative stakeholder groups (see Table 1) were conducted. Only in one case and due to the organisational restrictions pertaining, could the interview be carried out remotely through email. The groups were selected to cover the following categories of stakeholders: individuals, policy developers, researchers and regulators. Next representative groups for these stakeholder groups were assembled.

In total 11 interviews were conducted with 6 groups of representative stakeholders involved in the drinking water governance of Ireland. The groups were selected to cover the diverse ranges of stakeholders with various specialities and interests in the governance structure. The selected groups are believed to have a comprehensive knowledge about the water governance and water quality situation in Ireland. Two sets of group work exercises (A and B) were designed for each representative stakeholder group:

- Exercise A, each representative stakeholder group was asked to map out the water governance framework from their perspective.

- Exercise B, each representative stakeholder group was asked to map out the important factors affecting the provision of good drinking water quality in agricultural areas.

The average time to finish the Exercise A and B was 90 and 60 min, respectively.
Before Exercise A and B started, the FCM method and the design of the two exercises were presented to each representative stakeholder group and ample time was allocated for questions to ensure each group understood the process involved. As recommended by Ozesmi and Ozesmi (2003) the subject of the study was presented as a question and participants were asked to think about the factors of importance which may affect the subject. The question posed to groups for Exercise A was: In Ireland, who do you think are the actors/stakeholders involved in the water governance regulatory framework and how are they connected? The question posed to groups for Exercise B was: In Ireland, what are the factors of importance and how are these connected for provision of good drinking water quality in agricultural areas?

\subsubsection{Exercise $A$ - water governance map}

At the beginning of Exercise A (the water governance framework map) each group was given a paper sheet $\left(4800 \mathrm{~cm}^{2}\right)$ containing the actors/stakeholder groups as in Table 2, in random order on printed cards that could be re-arranged and fixed to the sheet. These actors/stakeholders were compiled after a review by the authors but were not exhaustive. Representative stakeholder groups were advised and free to add or subtract from this table as they so wished based on their knowledge of the system. Blank cards were also provided and a series of colour markers. The stakeholders' participants were informed about the authors' point of view regarding the integrative water governance and that everyone's role in the systems is seen important.

The groups were then asked to engage in a discussion assisted by the facilitator to identify other actors/stakeholders not included in Table 2 and these were added to the blank cards provided. The groups were then asked to connect all stakeholder cards on the sheet of paper using directional arrows and to weight these connections. A fuzzy logic key was developed and used to transform words into values i.e. the weights were either positive or negative i.e. having an existing efficient connection $(+1,+2)$ or a conflicting or missing connection $(-1$, $-2,-3)$. The purpose of the key was explained to stakeholder representative groups.

\subsubsection{Water quality indicators}

At the beginning of Exercise B (water quality factors of importance) each group was given a paper sheet $\left(1274 \mathrm{~cm}^{2}\right)$ containing nine pre-defined indicators as in Table 3 , in random order on printed out cards which could be re-arranged and fixed to the sheet. Blank cards were also provided and a series of colour markers. The predefined indicators were chosen from the literature (Blackstock et al., 2010; Hyland et al., 2018a, 2018b; Micha et al., 2020) or based on the collective expert knowledge of the authors. Indicators were divided into three main categories i.e. social, environmental and economic and were selected based on the following criteria: 1) They are abstract ideas; 2 ) they are measurable in meso-scale agricultural catchments; 3 ) they are relevant to EU agricultural legislation and 4) they affect water quality directly.

The same process was repeated as in Exercise A regarding an initial discussion, addition of any other indicators not already provided and then connecting these indicators and assigning weights. Such connections or relationships between the variables (degree of influence) gives information on how these factors affect each other. In this phase another fuzzy logic key was used to transform word into values as the

Table 1

Representative stakeholder group information for interviews in two water governance exercises for FCM.

\begin{tabular}{|c|c|c|c|c|}
\hline Stakeholder group & People in each group & Male & Female & Notes \\
\hline Catchments Scientist & 5 & 4 & 1 & Scientists, advisors and technicians providing measures supporting good water quality \\
\hline Water Initiative Officer & 3 & 2 & 1 & Agriculture advisors safeguarding water quality in farmlands \\
\hline Environmental Researcher & 5 & 2 & 3 & Scientists with background in water, soil and air \\
\hline Policy Maker & 3 & 2 & 1 & Representatives working in agriculture and water quality area \\
\hline Local Authority & 2 & 2 & 0 & Representatives working in protection of drinking water in agricultural areas \\
\hline Water Service Provider & Unknown & Unknown & Unknown & Mixture of team members with main responsibility of water and gas networks \\
\hline
\end{tabular}


Table 2

Actors and stakeholders involved in Ireland water governance activities and a summary of roles.

\begin{tabular}{|c|c|}
\hline Actors and stakeholders & Description \\
\hline EU WFD & $\begin{array}{l}\text { A framework for protection of surface and } \\
\text { groundwater under environmental } \\
\text { legislation }\end{array}$ \\
\hline $\begin{array}{l}\text { Department of Housing, Planning } \\
\text { and Local Government }\end{array}$ & $\begin{array}{l}\text { Helping local authorities to plan and build } \\
\text { better and more houses for people }\end{array}$ \\
\hline $\begin{array}{l}\text { Department of Communications, } \\
\text { Climate Actions and } \\
\text { Environment }\end{array}$ & $\begin{array}{l}\text { Responsible for delivery of policies and } \\
\text { programs in a number of areas ensuring that } \\
\text { policies are in line with EU obligations }\end{array}$ \\
\hline $\begin{array}{l}\text { Department of Agriculture Food } \\
\text { and the Marine }\end{array}$ & $\begin{array}{l}\text { Development and implementation of } \\
\text { national and EU schemes in support of } \\
\text { agriculture, food, forestry and rural } \\
\text { environment }\end{array}$ \\
\hline $\begin{array}{l}\text { Commission for Regulation of } \\
\text { Utilities }\end{array}$ & $\begin{array}{l}\text { Ireland's independent energy and water } \\
\text { regulator }\end{array}$ \\
\hline Environmental Protection Agency & $\begin{array}{l}\text { Responsible for protecting and improving the } \\
\text { environment as a valuable asset for the } \\
\text { people of Ireland }\end{array}$ \\
\hline Pesticide Control Division & $\begin{array}{l}\text { Responsible for implementing the regulatory } \\
\text { system for plant protection and biocidal } \\
\text { products }\end{array}$ \\
\hline Teagasc & $\begin{array}{l}\text { Providing research, advisory and training } \\
\text { services to the agriculture and food industry }\end{array}$ \\
\hline ERVIA & $\begin{array}{l}\text { Commercial company responsible for } \\
\text { delivery of Ireland's national gas and water } \\
\text { infrastructure and services }\end{array}$ \\
\hline Health Service Executive & $\begin{array}{l}\text { Responsibility to support the people of } \\
\text { Ireland in health and social care services }\end{array}$ \\
\hline Irish Water Ltd & $\begin{array}{l}\text { Responsible for the operation of public water } \\
\text { and wastewater services. Part of ERVIA group }\end{array}$ \\
\hline $\begin{array}{l}\text { Agricultural Catchments } \\
\text { Programme }\end{array}$ & $\begin{array}{l}\text { Main aim is to support water quality } \\
\text { objectives and the production of high-quality } \\
\text { food }\end{array}$ \\
\hline Local Authorities & $\begin{array}{l}\text { Town and county councils responsible for } \\
\text { different water services regionally }\end{array}$ \\
\hline House Holders & $\begin{array}{l}\text { Irish citizens using water for different } \\
\text { residential purposes and daily needs }\end{array}$ \\
\hline $\begin{array}{l}\text { Agricultural Sustainability } \\
\text { Advisors }\end{array}$ & $\begin{array}{l}\text { Work with farmers towards more sustainable } \\
\text { farming, reduce impact of farming in areas of } \\
\text { action and to improve nutrient management }\end{array}$ \\
\hline $\begin{array}{l}\text { Local Authority Water Science and } \\
\text { Advice }\end{array}$ & $\begin{array}{l}\text { A group of scientists assisting Local } \\
\text { Authorities to support WFD activities }\end{array}$ \\
\hline $\begin{array}{l}\text { National Federation of Group } \\
\text { Water Schemes }\end{array}$ & $\begin{array}{l}\text { Representative and negotiating organisation } \\
\text { for community-owned rural water supplies } \\
\text { in Ireland }\end{array}$ \\
\hline Local Authority Waters Program & $\begin{array}{l}\text { Implement River Basin Management Plans in } \\
\text { Ireland, as required by the EU Water Frame- } \\
\text { work Directive }\end{array}$ \\
\hline Irish Farmers Association & $\begin{array}{l}\text { Representing the interests of Irish farmers } \\
\text { together with lobbying and campaigning for } \\
\text { improved conditions and incomes for farm } \\
\text { families }\end{array}$ \\
\hline Farming co-operatives & $\begin{array}{l}\text { Groups of farmers coming together to } \\
\text { safeguard the price of milk who at the same } \\
\text { time are shareholders in the company }\end{array}$ \\
\hline Farmers & $\begin{array}{l}\text { Water users for purpose of food and dairy } \\
\text { production, and cattle }\end{array}$ \\
\hline Private Advisors & $\begin{array}{l}\text { Their role is in paid consultancy and advice } \\
\text { for the farm enterprise. }\end{array}$ \\
\hline Dairy Industry & $\begin{array}{l}\text { Representing the interests of Ireland's dairy } \\
\text { processors, through a comprehensive advi- } \\
\text { sory service, and representation at national, } \\
\text { EU and international level }\end{array}$ \\
\hline
\end{tabular}

casual relationships were assigned as negatively high to positively high: $(---,--,-$, Neutral,,,++++++$)$.

\subsection{Data analysis}

In order to interpret and analyse the different representative stakeholder group perceptions from Exercises A and B, FCMs were constructed from the worksheets of each stakeholder group. The visualization and some preliminary analysis of the maps were conducted using Gephi@ software as used previously by others (e.g. Bastian et al., 2009; Bruns, 2012; Heymann and Le Grand, 2013; Jacomy et al., 2014; Micha et al., 2020). Each map contains "nodes" which are representative of variables (actors/indicators provided by authors or added by interviewees) and "edges" which illustrate the connections (arrows drawn by interviewees) between variables. The weights of the connections were imported to the software and influenced the thickness of the edges, i.e. the thicker lines have stronger weights. In summary the FCMs are converted to matrices where in the case of connections between two variables the matrix array is given the value (Ozesmi and Ozesmi, 2003; Ozesmi and Ozesmi, 2004; Micha et al., 2020) in the form of:

$A(D)=\left[\alpha_{i j}\right]$

where $A(D)$ is the square matrix of variables in which $\alpha_{i j}$ is placed in row $i$ and column $j$.

\subsection{Graph theory indices and neural network analysis}

In this study FCM was used to describe the interactions among actors or stakeholders. Fuzzy Cognitive Maps are complex due to the large number of nodes (variables, factors) and the connections among them, and hence it is not possible to predict their behaviour by only focusing on each unit (Ozesmi and Ozesmi, 2003; Ozesmi and Ozesmi, 2004). To aid the process graph theory is an established method used to analyse FCMs (Ozesmi and Ozesmi, 2003; Ozesmi and Ozesmi, 2004) and to interpret each drawn map. These kinds of in-depth analyses provide important information such as the stakeholder perception of a certain topic, the hierarchal point of view, and environmentalecological management scenarios. Some of the basic indices of FCMs include: $\mathrm{N}$ - number of nodes (variables), $\mathrm{C}$ - number of connections (edges) between nodes, $\mathrm{D}$ - density of the map which is representative of how connected the map is:

$D=\frac{C}{(N(N-1))}$

Out-degree $\left(\operatorname{od}\left(v_{i}\right)\right)$ is defined as the cumulative weights of connections exiting in a node, in-degree $(i d(v i))$ is the cumulative weights of connections entering a node and Centrality $\left(C_{e n}\right)$ is the summation of in-degree and out-degree and represent the contribution of a variable in the map (Harary et al., 1965; Ozesmi and Ozesmi, 2003). Two important types of nodes in a map are transmitter nodes and receiver nodes. Transmitter nodes are those that have zero in-degree and a positive out-degree. Receiver nodes, on the other hand, have zero out-degree and positive in-degree.

The Hierarchy Index $(h)$ is another useful indicator which reflects the perceptions of stakeholders' opinion on a map structure, and is expressed as:

$h=\frac{12}{(N-1)(N)(N+1)} \sum_{i}\left[\frac{\left.\operatorname{od}\left(v_{i}\right)-\sum o d\left(v_{i}\right)\right)}{N}\right]^{2}$

where $N$ in the number of nodes and $\operatorname{od}\left(v_{i}\right)$ is the out-degree of the map. If $h$ is equal to 0 the system is entirely democratic and when equal to 1 it is fully hierarchical. This is an important differentiation. Hierarchical governance approaches facilitate top-down decision making, are routinely criticised for being inefficient, unresponsive, and not flexible to learning and adaptation (Flores et al., 2016; Akhmouch and Clavreul, 2016; Jimenes et al., 2020). Integrative, adaptive, collaborative, and transparent water governance (i.e. a democratic governance approach) is hypothesised to be more effective under stress and change (Miller, 2011; Nelson et al., 2008; Kirchhoff and Dilling, 2016). This is an important distinction among representative stakeholder groups and important in terms of providing solutions to bottlenecks within the current system of regulation. 
Table 3

Pre-defined indicators used in the Exercise B.

\begin{tabular}{|c|c|c|c|}
\hline Category & Pre-selected indicator & Units & Description \\
\hline \multirow[t]{3}{*}{ Social } & Farmers knowledge (education, training) & Nominal & Knowledge gained from advisors, training, workshops etc. \\
\hline & Farmers behaviour and belief & Nominal & Farmers' willingness to participate and adopt BMPs above the baseline \\
\hline & Connectivity of stakeholders & Nominal & The way different sectors are interacting with each other \\
\hline \multirow[t]{4}{*}{ Environmental } & Nutrient use efficiency & $\%$ & $\begin{array}{l}\text { Achievement of less than nitrogen } \mathrm{MAC}^{\mathrm{a}}\left(<50 \mathrm{mg} \mathrm{l}^{-1} \text { or }<11.3 \mathrm{mg} \mathrm{l}^{-1} \mathrm{NO}_{3}-\mathrm{N} \text { for drinking }\right. \\
\text { water) and phosphorus }\left(<0.035 \mathrm{mg} \mathrm{l}^{-1} \text { for surface water }\right)\end{array}$ \\
\hline & Total pesticides & $\mu g l^{-1}$ & Applied by farmers (not exceeds $0.5 \mu \mathrm{g} \mathrm{l}^{-1}$ ) \\
\hline & $\mathrm{MCPA}^{\mathrm{b}}$ & $\mu g \mathrm{l}^{-1}$ & Applied by farmers (not exceeds $0.1 \mu \mathrm{g} \mathrm{l}^{-1}$ ) \\
\hline & $\begin{array}{l}\text { BMPs (Buffer zones, cover crops, biodiversity) } \\
\text { and Water treatment facilities }\end{array}$ & $\begin{array}{l}\% \text { of } \\
\text { uptake }\end{array}$ & $\begin{array}{l}\text { Best management practices implemented by farmers and water treatment methods } \\
\text { implemented }\end{array}$ \\
\hline \multirow[t]{2}{*}{ Economic } & Farmers' income (production) & $€$ & Farmers' income from farm products \\
\hline & Cost of BMPs (required labour, land availability) & $€$ & Cost and efforts to apply BMPs in lands \\
\hline
\end{tabular}

\footnotetext{
Maximum allowable concentration.

b 2-Methyl-4-chlorophenoxyacetic acid (selective herbicide).
}

It must also be noted that the outcomes of the present study pertain to the representative group and not to the organisation they are part of.

Further analysis of FCMs was achieved following the neural network methodology of Reimann (1998). The steady-state phase of the maps presents the outcome of the cognitive maps and not necessarily their current shape. To achieve the steady-state condition of the system, the "auto-associative neural network method" (Reimann, 1998; Ozesmi and Ozesmi, 2003) was used where a vector of initial values of variables is multiplied by the resulted FCM square matrix:

where $I^{n}$ is the vector of initial variables, and $A$ is the square FCM matrix.

The resulting vector was then multiplied to the matrix and normalised, and this procedure continued until the values became stabilised. In this study all the FCMs reached their steady-state conditions in less than 20 iterations. Steady-state calculations provide the rankings of variables in comparison to each other. Once the steady-state condition was obtained, some of the indicators/variables were changed to perform policy option scenarios by fixing them at a desirable value at each step of the iteration and to analyse the results when the system falls to the steady-state condition (Kosko, 1987; Ozesmi and Ozesmi, 2003; Ozesmi and Ozesmi, 2004). Comparing the results of scenarios with the steady-state condition of the system will give an indication of the effect of different policies on the whole system. For example, a variable may be set to 1 for a highly desirable condition or to 0 for a low equivalent at each iteration step. When the system been stabilised, by subtracting the modelled steady state value to the initial one the percentage of variation was calculated. Based on the steady-state results some policy options were conducted to achieve what-if scenarios and decision-making options. Scenario development is a new tool in environmental sciences and has a key role in the achievement of longterm environmental goals (Kok, 2009). Direct stakeholders' participation and scientific input of models can ensure that scenarios provide credible information (Kok, 2009). The main purpose of scenario simulation is to avoid the problem of unforeseeable changes and instead to provide outcomes for future planning. FCM-based scenarios have been built based on integrated perspectives of stakeholders and their results can be used either as an independent output or an input for the generation of new policies (Jetter and Kok, 2014).

Scenarios were tested by changing the following to the highest level of influence (i.e. keeping its value equal to one for every iteration phase): 1) Farmers knowledge, 2) BMP uptake and 3) Farmers behaviour and belief.

\section{Results and discussion}

\subsection{Exercise A: water governance map}

The water governance map of the Catchment Scientists representative group is presented in Fig. 1 and the complete stakeholder group FCMs are provided in Supplementary material Figs. S2-S7 along with a detailed table of results giving a comparison of FCM components, indegree, out-degree and degree of $\mathrm{C}_{\mathrm{en}}$ (Table $\mathrm{S} 1$ ).

The number of variables and connections provided by each group alongside the graph theory indices of the water governance map are presented in Table 4. The Water Initiative Officers, Policy Makers, Local Authorities and Water Service Providers representative groups did not provide any transmitter variables while Catchment Scientists and Environmental Researchers added five and three, respectively. This indicated that the latter two groups sought more options for participation and regulation of stakeholders in the governance structure. This may be due to the fact that they currently perceive some of the actors/stakeholders within the system as dependant on others and under their control (Ozesmi and Ozesmi, 2003).

The interviewees could weigh the connections by either a positive or a negative value. The latter meaning a connection which should exist among stakeholders but currently does not and the higher negative weights mean a higher adverse effect on the governance map. According to the Catchment Scientist stakeholder representative group the highest missing connections for stakeholders were the "NGOs". For the Water Initiative Officers and the Local Authority stakeholder representative groups this was the "householders", and the Policy Maker representatives thought this was "Bord Bia (Irish Food Board)". Among the interviewed groups it was the Policy Maker stakeholder representative group that provided the highest number of negative connections. According to this group, as well as Bord Bia, the meat industry, private advisors, the dairy industry, universities and the Department of Communication, Climate and Environment were other organisations with missing connections.

The Water Initiative Officer stakeholder representative group had a high hierarchy index value. This indicated a belief that organisations are more likely to be dictating to each other or working with more dependency rather than collaborating with others. The other groups had a lower hierarchy index and therefore are considered more democratic. This perspective is likely to be open and engaged to implement changes and management objectives. Democratic maps have been found to be more flexible to environmental conversion since they have a higher "level of integration and dependence" (Sandell, 1996; Ozesmi and Ozesmi, 2003). As all maps fell into a steady-state condition in less than 20 iterations scenario testing could be facilitated. Fig. 2 illustrates the first three highest ranked actors/stakeholders according to each representative stakeholder group after reaching this steady state condition. 


\begin{tabular}{|ll}
\hline 2.0 & $(11.54 \%)$ \\
7.0 & $(11.54 \%)$ \\
16.0 & $(11.54 \%)$ \\
4.0 & $(7.69 \%)$ \\
5.0 & $(7.69 \%)$ \\
6.0 & $(7.69 \%)$ \\
9.0 & $(7.69 \%)$ \\
11.0 & $(7.69 \%)$ \\
-4.0 & $(3.85 \%)$ \\
0.0 & $(3.85 \%)$ \\
1.0 & $(3.85 \%)$ \\
10.0 & $(3.85 \%)$ \\
12.0 & $(3.85 \%)$ \\
20.0 & $(3.85 \%)$ \\
22.0 & $(3.85 \%)$ \\
\hline
\end{tabular}

\section{Nodes Centrality distribution and colour legend of map}

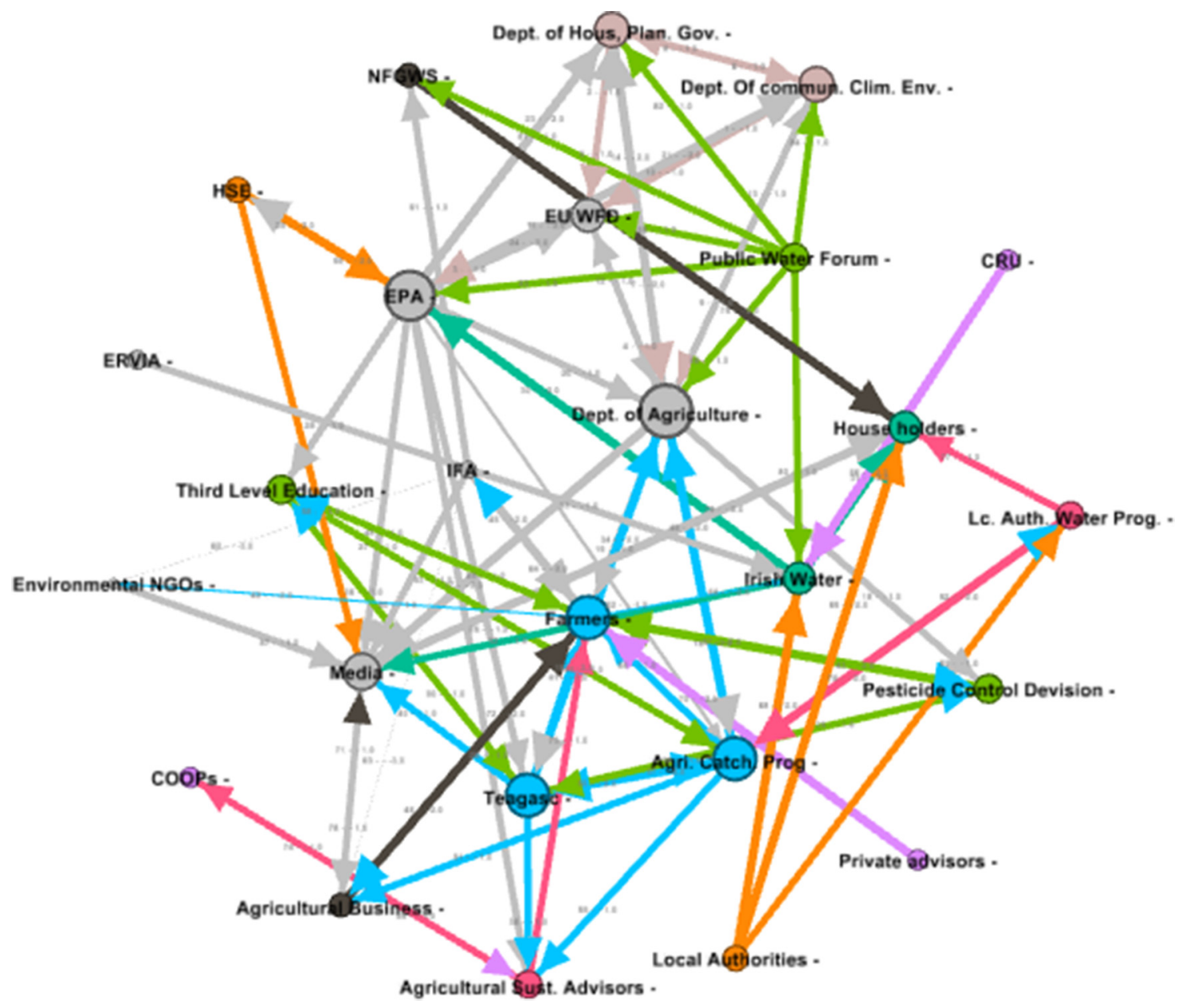

Fig. 1. FCM map of water governance map, Catchment Scientist group.

Farmers were ranked as the most important group by Catchment Scientist and Water Initiative Officer stakeholder representative groups and the third most important by the Environmental Researchers (Fig. 2). The "Department of Agriculture", the highest governmental actor in contact with farmers, was ranked as the most important group by Environmental Researchers and the second most important by Catchment Scientists. "Teagasc", as the research, advisory and training service provider to agriculture and food producers, was viewed as important by different groups. Policy Makers, Environmental Researchers and the Local Authority group ranked "Teagasc" as the second most important actor among all and Catchment Scientists ranked them as third. "EPA", the main environmental regulatory body of the country, was ranked first by Policy Makers and the Local Authority group. The important point regarding the steady state ranking of actors is evident for the Water Service Provider group. Although most of the stakeholders' representatives, viewed this group at moderate to low ranking of efficiency due to the high number of missing connections (Catchment Scientist: 0.42, Water Initiative Officers: 0.21, Environmental Researchers: 0, Local Authorities: 0.19), the Water Service Provider group believed that they had a central and efficient position in the governance map. Also, the Water Service Provider group, did not 
Table 4

Map results for different stakeholder groups with respect to Exercise A.

\begin{tabular}{|c|c|c|c|c|c|c|}
\hline & $\begin{array}{l}\text { Catchment } \\
\text { Scientists }\end{array}$ & $\begin{array}{l}\text { Water } \\
\text { Initiative } \\
\text { Officers }\end{array}$ & $\begin{array}{l}\text { Environmental } \\
\text { Researchers }\end{array}$ & $\begin{array}{l}\text { Policy } \\
\text { Makers }\end{array}$ & Local Authorities & $\begin{array}{l}\text { Water } \\
\text { Service } \\
\text { Providers }\end{array}$ \\
\hline No. of variables & 26 & 29 & 26 & 29 & 27 & 48 \\
\hline No. of connections & 88 & 135 & 90 & 130 & 113 & 94 \\
\hline No. of receiver variables & 1 & 1 & 0 & 1 & 1 & 0 \\
\hline No. of transmitter variables & 5 & 0 & 3 & 0 & 0 & 0 \\
\hline Density & 0.13 & 0.16 & 0.14 & 0.16 & 0.16 & 0.042 \\
\hline Highest-weighed variables & Dept. of Ag. & Farmers & Teagasc & EPA & EPA & Irish Water \\
\hline Highest- missing variables & NGOs & Householders & - & Bord Bia & $\begin{array}{l}\text { Householders (Private } \\
\text { wells) }\end{array}$ & - \\
\hline Hierarchy Index & 0.28 & 0.58 & 0.34 & 0.28 & 0.21 & 0.04 \\
\hline
\end{tabular}

mention any of the other interviewed groups in their map. While this group perceived a positive connection with householders most of the interviewed group perceived them to have a negative connection.

\subsection{Exercise B: water quality indicators}

Water quality indicators map of the Catchment Scientists representative group is indicated in Fig. 3. All stakeholder group FCMs are provided in Supplementary material Figs. S8-S12 along with a summary table of results giving a comparison of FCM components, in-degree, out-degree and degree of centrality (Table S2).

The number of variables and connections provided by each group alongside the outcome indices for this phase of the study are presented in Table 5.

The Catchment Scientists and Policy Makers groups provided more transmitter variables in their FCMs indicating that they see drinking water quality being affected by other factors. Factors which negatively affected others were found in each of the stakeholders' FCMs. The Catchment Scientists group believed that "Poor drainage soils", "Rented land", "Excessive rainfall" and "Farm intensity" had the highest negative effects on other factors, respectively. Water Initiative Officers thought that "Extreme weather", "Soil type" and "Cost of BMPs" had the most negative effects on other factors. The Policy Makers group rated "Old age farmers" and "Cost of BMPs" as the highest negative factors, the Environmental Researchers thought the only negative factor was the "Cost of BMPs", and the Local Authorities believed "Slurry storage", "Cost of BMPs" and "Farmers knowledge" were the most negative factors.

The hierarchy index of 1 shows that the Policy Makers, Water Initiative Officers and the Local Authorities had a top-down point of view regarding the topic and are unlikely to adapt to changes in managing environmental issues at present. Research shows that enabling such groups to work together would result in a less hierarchical map and likely produce more democratic and creative solutions (Ozesmi and Ozesmi, 2003). Calculating the steady conditions of maps in Exercise $\mathrm{B}$, the stable state was reached in less than 20 iterations, so facilitating scenario testing. The highest-weighted variables among the groups were abstract ideas of "Farmers behaviour and belief", and "Farmers knowledge" which highlighted their importance and contribution among other variables and therefore is a good starting point to make positive changes in the map. When comparing the steady-state phase for the first three-highest ranked variables for each group interview "Nutrient concentration in water" was seen as the most important variable by the Catchment Scientists and Policy Makers and "Nutrient use efficiency" the second most important factors according to both Catchment Scientists and Water Initiative Officers (Fig. 4). "Applied total pesticides" was also the second most important factors according to the Environmental Researchers and Local Authority groups. "Farmers income" was the third most important variable according to the Water Initiative Officers and the Environmental Researchers.

As outlined in the Materials and methods section, three indicators were chosen in this study to test as the scenario. "Farmers knowledge" and "Farmers behaviour and belief" indicators were selected since both were among the highest-weighted variables in almost all analysed FCM maps. This indicated their importance to stakeholders and can be considered as a starting point to improve the system. The other indicator chosen to examine a scenario test was "BMP uptake", another high ranked factor, discussed frequently by participants during the interview sessions.

The results of the scenario testing were as follows: 1) "Farmers knowledge" at the highest level of influence resulted in the Catchment Scientists stakeholder representative group believing that "Farmers behaviour and belief" would increase to $45 \%$ and "Nutrient use efficiency" to 33\% (Fig. 5). The Policy Makers group thought that this change would result in a 39\% increase in the "Applied MCPA" efficiency and 34.5\% to

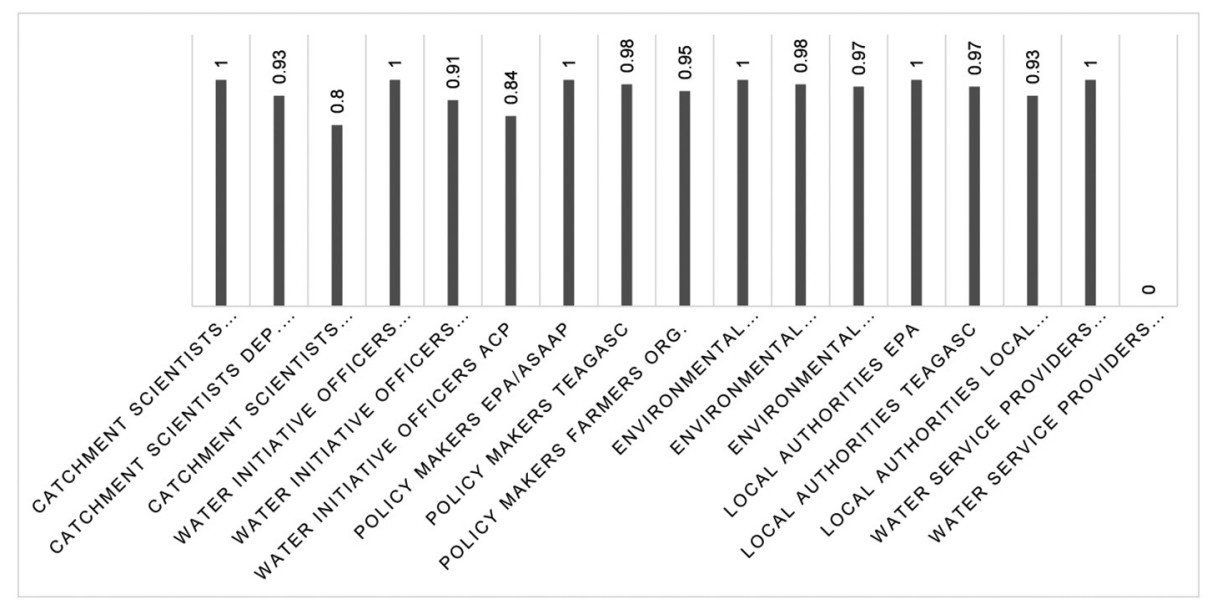

Fig. 2. The first highest-three ranked actors according to each stakeholders group in a steady-state condition in Exercise A. 


\begin{tabular}{|ll}
\hline 5.0 & $(23.81 \%)$ \\
9.0 & $(14.29 \%)$ \\
-3.0 & $(9.52 \%)$ \\
1.0 & $(9.52 \%)$ \\
3.0 & $(9.52 \%)$ \\
-6.0 & $(4.76 \%)$ \\
-2.0 & $(4.76 \%)$ \\
2.0 & $(4.76 \%)$ \\
4.0 & $(4.76 \%)$ \\
10.0 & $(4.76 \%)$ \\
14.0 & $(4.76 \%)$ \\
22.0 & $(4.76 \%)$
\end{tabular}

\section{Nodes Centrality distribution and colour legend of map}

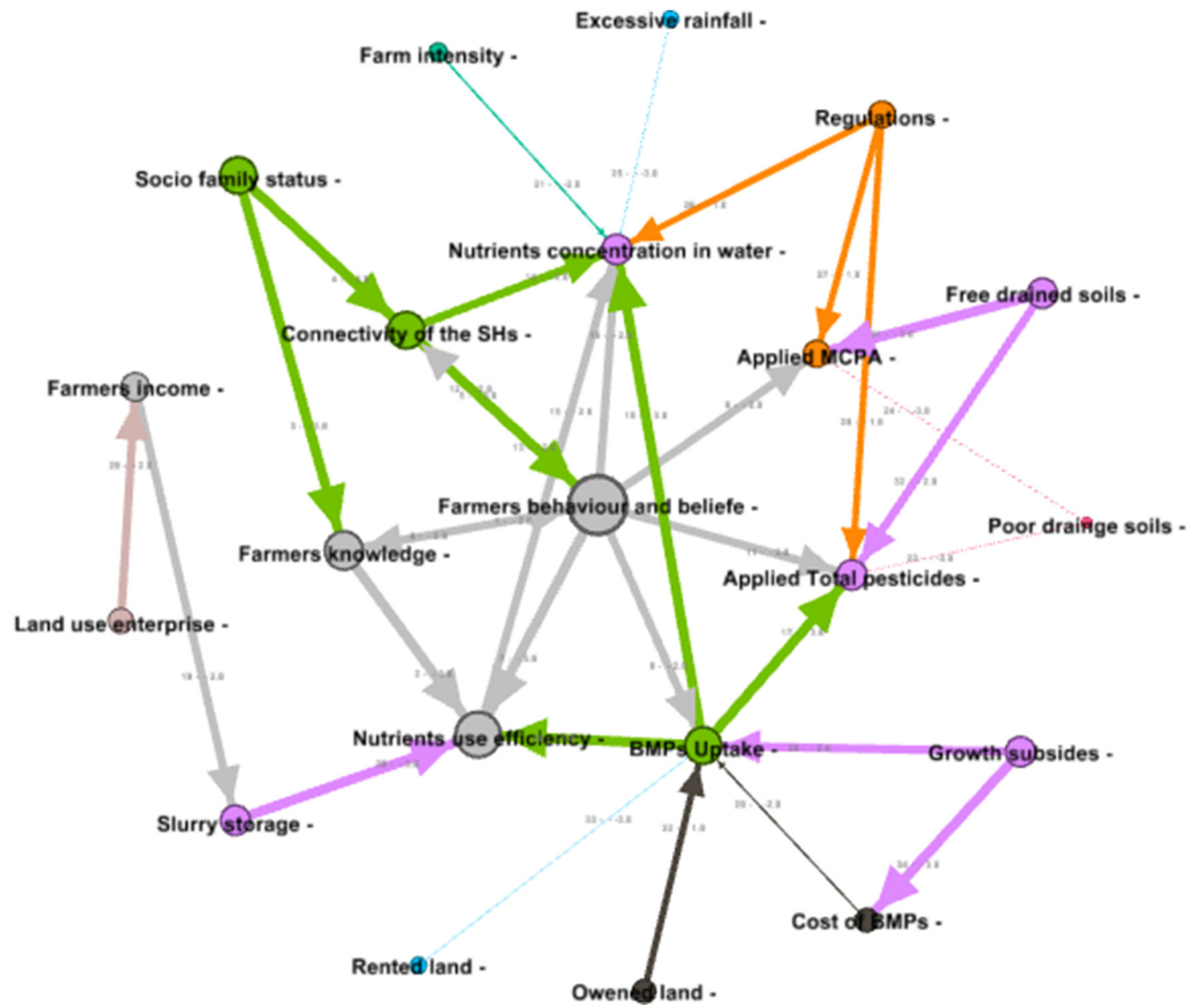

Fig. 3. FCM map of water quality indicators, Catchment Scientist group.

"Applied total pesticide" and "Behaviour and belief". Water Initiative Officers saw the changes as a 9\% increase to "Farmers behaviour and belief", $16 \%$ increase to "Regulations" and $2.5 \%$ to the "Applied total pesticide". Therefore, according to this scenario, the benefits of training and advisory at a high level would lead to some knock on benefits for environmental factors such as water quality, 2) "BMP uptake" at the highest level of influence did not result in considerable impact on other variables (Fig. 6). The Environmental Researchers believed this would increase the "Nutrient use efficiency" by $52 \%$. The Catchment Scientists believed this would raise the "Applied total pesticide" by $44 \%$. The result here showed the importance of training. It demonstrates a belief that implementation of best management practices to safeguard water quality without the necessary training may not result in environmental gains, 3) "Farmers behaviour and belief" at the highest level the Catchment Scientists group provided a high rate of increase for this change as they perceived this would lead to a $47 \%$ increase to "Farmers knowledge", "Connectivity of stakeholders", "BMPs uptake" and "Applied MCPA" (Fig. 7). The Water Initiative Officers group, on the other hand, believed that this scenario would lead to a $19 \%$ increase in "Farmers knowledge", 8\% increase to "Connectivity of stakeholders", $5 \%$ increase in "Nutrient use efficiency" and 7\% increase to "Farmers income". The Policy Maker group believed there would be a $15 \%$ increase in 
Table 5

Maps results of different groups in Exercise B - water quality indicators.

\begin{tabular}{|c|c|c|c|c|c|}
\hline & Catchment Scientists & Water Initiative Officers & $\begin{array}{l}\text { Environmental } \\
\text { researcher }\end{array}$ & Policy Makers & Local Authorities \\
\hline No. of variables & 21 & 15 & 19 & 17 & 12 \\
\hline No. of connections & 35 & 57 & 44 & 70 & \\
\hline No. of receiver variables & 3 & 1 & 3 & 3 & 0 \\
\hline $\begin{array}{l}\text { No. of transmitter } \\
\text { variables }\end{array}$ & 10 & 3 & 5 & 6 & 0 \\
\hline Density & 0.083 & 0.271 & 0.129 & 0.257 & 0.462 \\
\hline $\begin{array}{l}\text { Highest-weighed } \\
\text { variable }\end{array}$ & $\begin{array}{l}\text { Farmers behaviour and } \\
\text { belief }\end{array}$ & Farmers behaviour and belief & $\begin{array}{l}\text { Geographic } \\
\text { Location }\end{array}$ & $\begin{array}{l}\text { Farmers behaviour and } \\
\text { belief }\end{array}$ & $\begin{array}{l}\text { Farmers knowledge } \\
\text { (positive) }\end{array}$ \\
\hline $\begin{array}{l}\text { Highest-negative } \\
\text { variable }\end{array}$ & Poor drainage soil & $\begin{array}{l}\text { Soil type/extreme weather/cost of } \\
\text { BMPs }\end{array}$ & Cost of BMPs & Older age farmers & $\begin{array}{l}\text { Farmers knowledge } \\
\text { (negative) }\end{array}$ \\
\hline Hierarchy Index & 0.37 & 1 & 0.7 & 1 & 1 \\
\hline
\end{tabular}

"Nutrient use efficiency" and "BMPs uptake", a 30\% increase to the "Applied MCPA", 22\% increase to obtain "Regulations" and a 37\% increase to the "Applied total pesticide". The Environmental Researcher group assigned the highest increase i.e. 34\% and 10\% to "Farmers knowledge" and "Farmers income", respectively. The results here indicate the high importance of boosting the farmers' intentions and willingness in implementing measures which would be reached once they believe there to be a benefit from the outcome (Hyland et al., 2018a, 2018b). The map provided by the Local Authorities group did not provide a policy-option which was considerably different to other variables since the variables were too closely weighted to each other.

\section{Conclusions}

In two exercises, the presented method of using FCMs and graph theory analysis was suitable for comparing different actors' and stakeholders' perceptions on both water governance and the indicators affecting water quality. From our perspective, this is first time that FCM has been used to evaluate a governance structure. Based on stakeholder's perceptions three policy-options were run to suggest ways that future improvement of water quality could be achieved. Such scenario testing is uncommon in studies that focus on water quality or water governance. Indeed, the scenarios tested herein are only a few examples of other potential scenarios that could be investigated using the data gathered.

In Exercise A, most of the interviewed stakeholder representative groups showed a similar view with respect to "ranking and the importance" of the actors identified as being involved in the drinking water governance of Ireland. Some similarities were also found in Exercise B when ranking the factors of importance within an agricultural mesoscale catchment scenario to achieve good drinking water quality. For example, with the importance of "Nutrient concentration in water" and "Applied total pesticide". Identifying such similarities among stakeholders is a good foundation for collaboration on specific problems. Differences were also identified from the stakeholders' perception, for example the contrasting perceptions of the "Water Service Provider" role in Ireland, which could be perceived as a bottleneck to progress towards good drinking water quality.

The Hierarchal Index demonstrated that, apart from the Water Initiative Officers stakeholder representative group, the stakeholder groups had a relatively democratic view of water governance and are likely to be more open to engage and implement changes and management objectives. For the water quality indicators, only the Catchment Scientist stakeholder representative group showed a democratic point of view while others were fully hierarchal. These results suggest that asking these representative stakeholder groups to work together could lead to creative solutions.

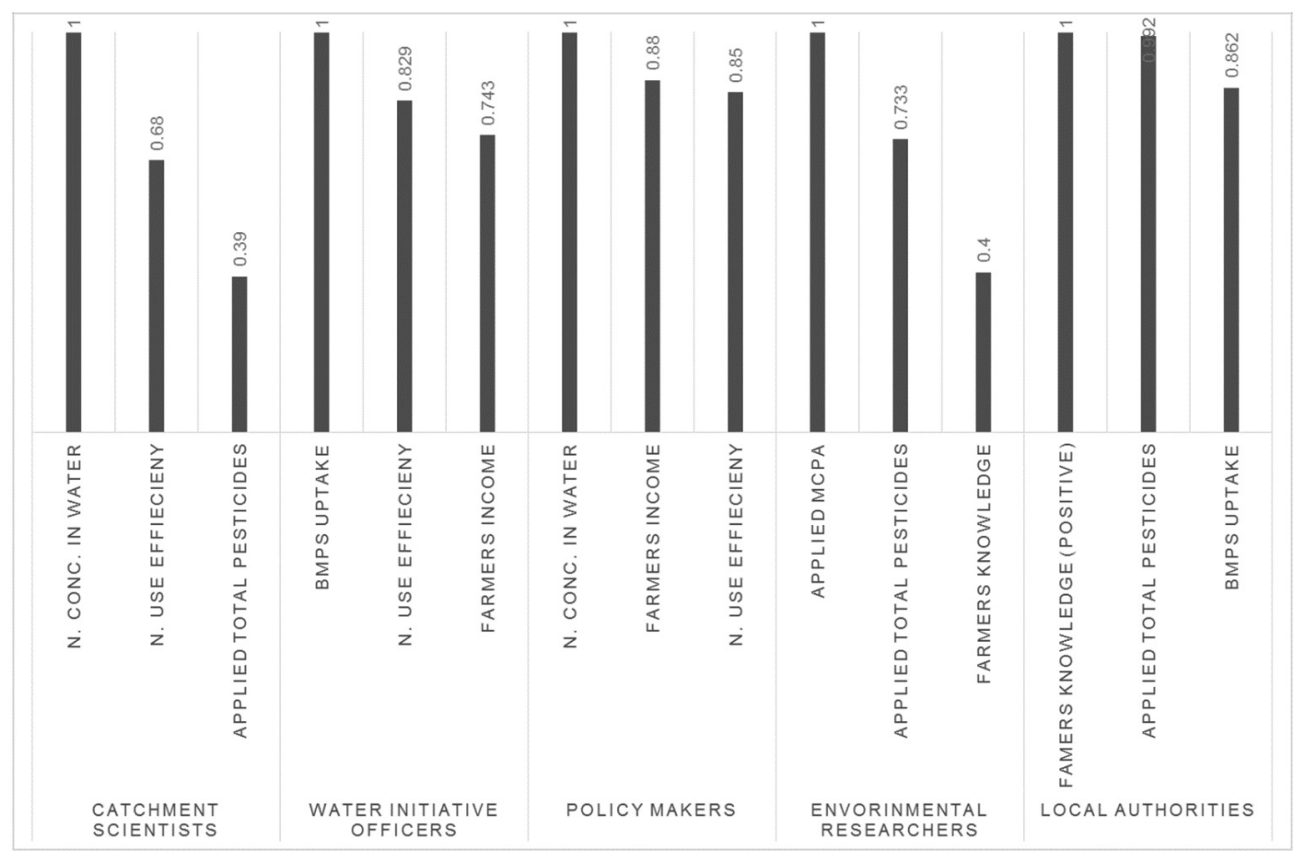

Fig. 4. The first highest-three ranked factors according to each stakeholders group in steady-state condition in Exercise B. 


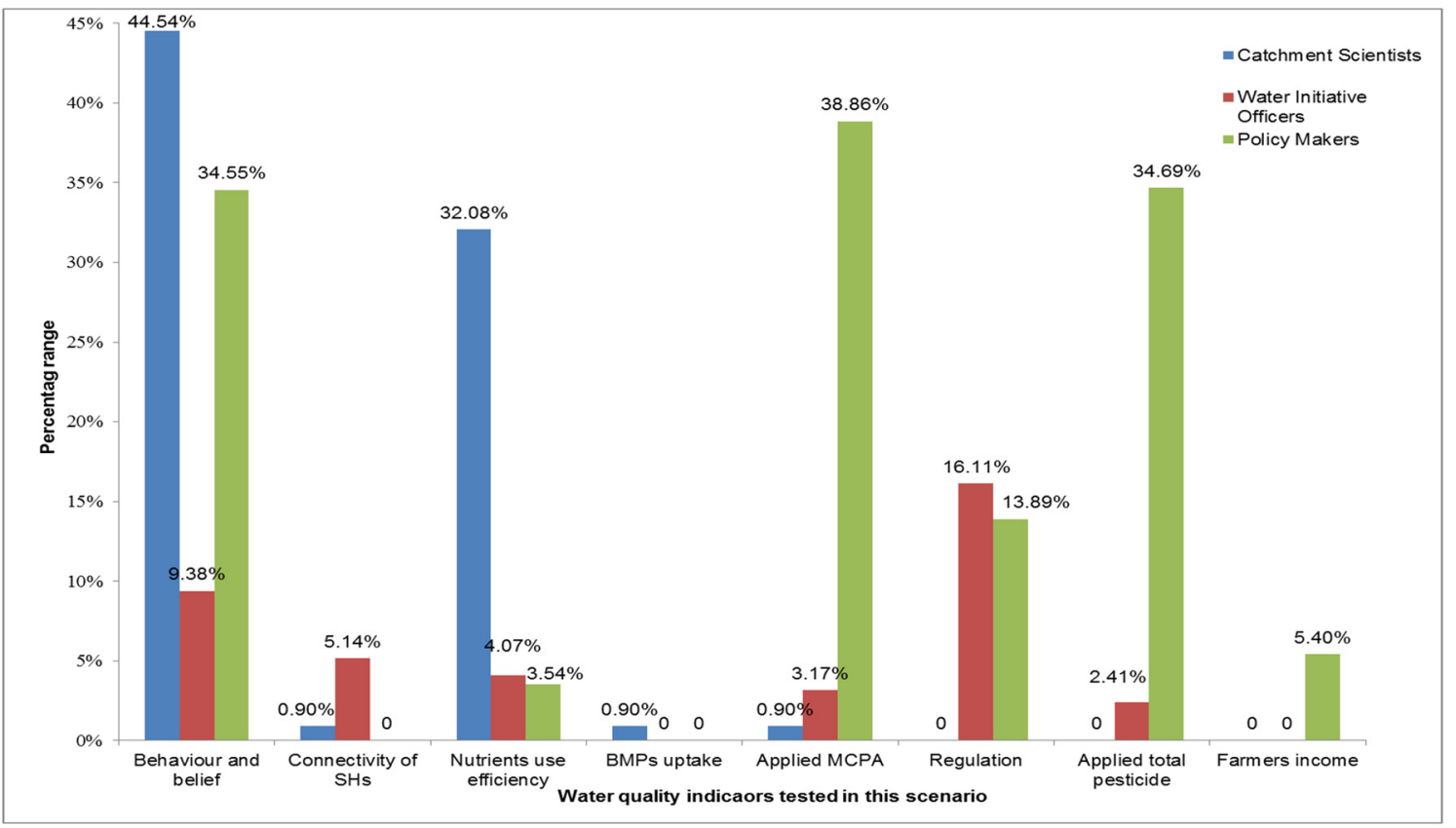

Fig. 5. Outcome of policy option 1: Farmers knowledge was fixed at the highest influence value.

Scenario testing of policy options enabled bottlenecks and possible solutions to be identified. For example, results suggested that boosting "Farmers behaviour and belief" to the highest possible level, would result in a large increase to other factors - a scenario where farmers could benefit from the outcome. This would be achieved by enhancing farmers' willingness and intention to participate and implement BMPs. Better results would be achieved if farmers believed in the method and could benefit from the outcome. Also keeping "Farmers knowledge" at the highest point had a positive influence on the other factors. This can be achieved by enhancing farmer training and advising by local and national actors.
Some recommendations for future research and study regarding this topic, using the FCM approach and other participatory modelling approaches that deal with perceptions, can be summarised as follows:

1. Each representative stakeholder group viewed the water governance framework from their own perspective, highlighting the need for knowledge transfer. Further fragmentation may be avoided by holding additional multi-stakeholder workshops with the aim of integrating the governance system and establishing one aggregated water governance map.

2. Polar ends of the water governance map were important. Most representative stakeholder groups saw "Farmers" and the "Department

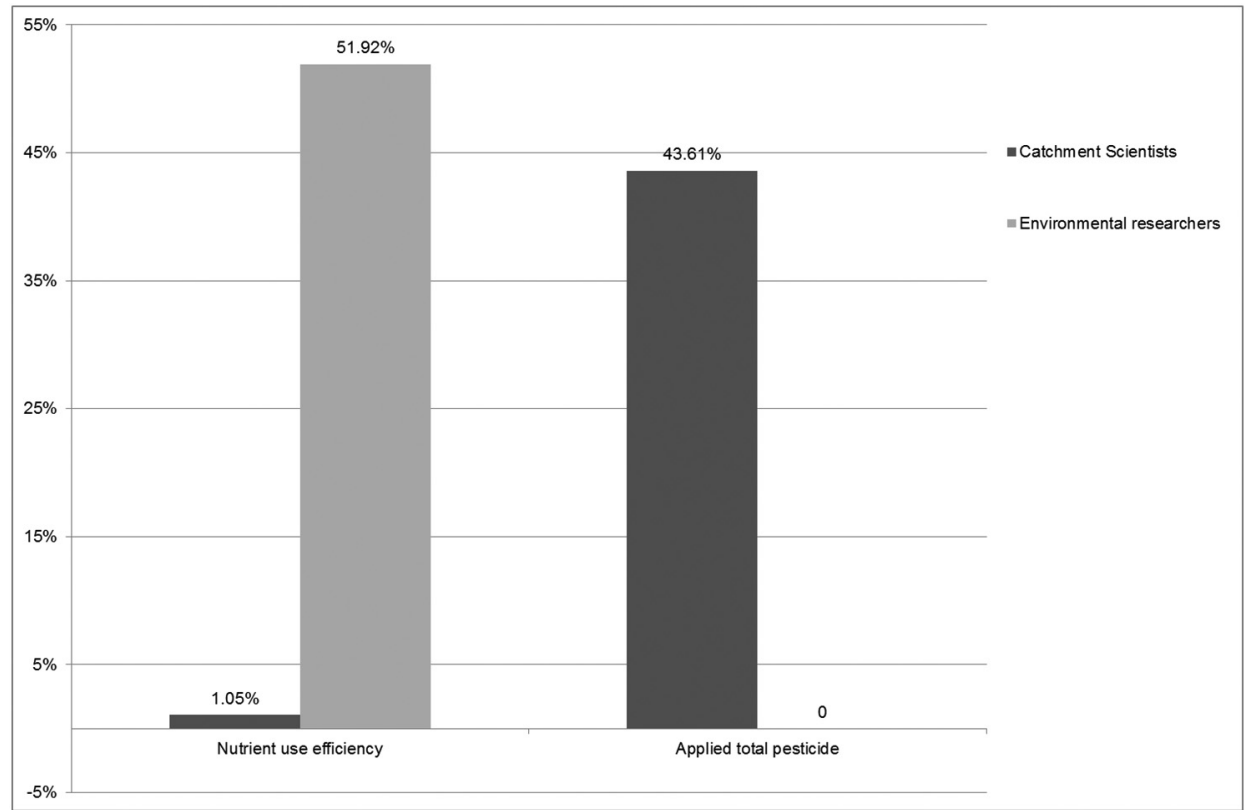

Fig. 6. Outcome of policy option 2: BMP uptake was fixed at the highest influence value. 


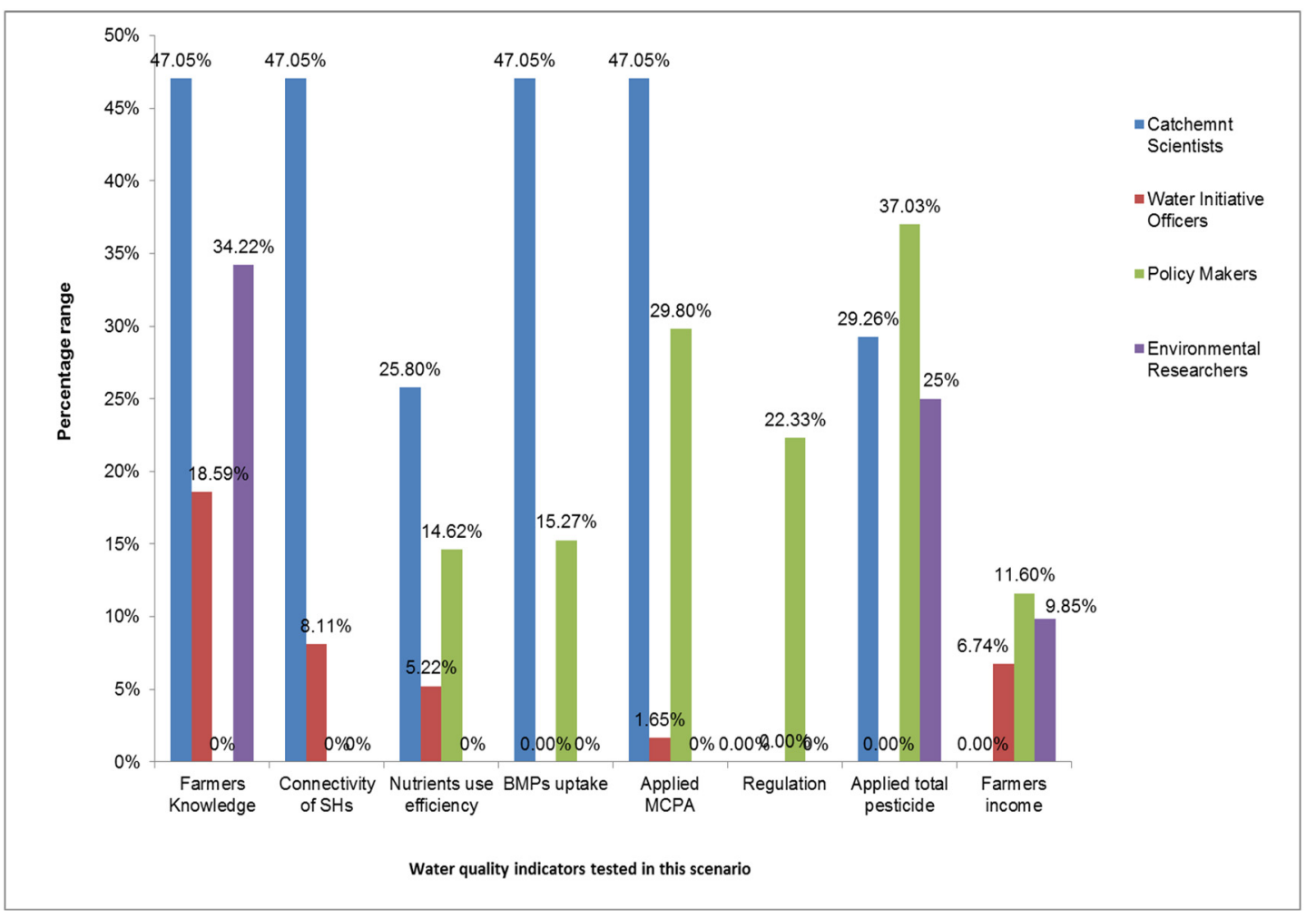

Fig. 7. Outcomes of policy option 3: Farmers behaviour and belief was fixed at the highest influence value.

of Agriculture" as the two most important actors to achieve good water quality within agricultural meso-scale catchments. It will be important that representatives from these groups interact, highlighting the role of organisations such as farmers' associations.

3. Stakeholder groups that were seen to have high missing connections in the governance structure should be encouraged to engage in collaborative water governance efforts.

4. The "Cost of BMPs" was believed to have the highest negative impact on other factors and on water quality and should be reviewed for solutions.

5. Studies such as this one that support sustainable water governance systems by integrating actors and stakeholders' perceptions and concerns in policy development and reviews are recommended for the future.

6. To do the same research studies in certain case studies, by applying the models which can factor in the biases and perceptions of national and local stakeholders while designing the methodology e.g. IPSM and CSH would be a next step in this context.

\section{CRediT authorship contribution statement}

Shahvi S writing, methodology, formal analysis, Mellander P-E writing - review \& editing, conceptualisation Jordan P writing - review \& editing, conceptualisation Fenton 0 writing -review \& editing, conceptualisation.

\section{Declaration of competing interest}

The authors declare that they have no known competing financial interests or personal relationships that could have appeared to influence the work reported in this paper.

\section{Acknowledgements}

This work has been carried out under the WaterProtect research project supported by the European Union Horizon 2020 - Research and innovation Framework programme [grant no. 727450]. The authors express their gratitude to all stakeholders participating in the interviews and to the Agricultural Catchments Programme for hosting the project.

\section{Appendix A. Supplementary data}

Supplementary data to this article can be found online at https://doi. org/10.1016/j.scitotenv.2020.142193.

\section{References}

Akhmouch, A., Clavreul, D., 2016. Stakeholders engagement for inclusive water governance: "practicing what we preach" with the OECD Water Governance Initiative. Water 8, 204. https://doi.org/10.3390/w8050204.

Arnold, R., Wade, J., 2015. A definition of systems thinking: a systems approach. Procedia Computer Science 44, 669-678. https://doi.org/10.1016/j.procs.2015.03.050.

Ashekuzzaman, S.M., Richards, K.G., Ellis, S., Tyrrel, S., O'Leary, E., Griffiths, B., Ritz, K., Fenton, O., 2018. Risk assessment of $E$. coli survival up to the grazing exclusion period after dairy slurry, cattle dung, and biosolids application to grassland. Frontiers in Sustainable Food Systems 2 (34). https://doi.org/10.3389/fsufs.2018.00034.

Axelrod, R., 1976. Structure of Decision: The Cognitive Maps of Political Elites. Princeton University Press, Princeton, NJ.

Bakker, K., Cook, C., 2011. Water governance in Canada: innovation and fragmentation. International Journal of Water Resources Development 27 (2), 275-289. https://doi. org/10.1080/07900627.2011.564969.

Bastian, M., Heymann, S., Jcomy, M., 2009. An Open Source Software for Exploring and Manipulating Networks, gephi. 2009 (Org/publications/gephi-bastian-feb09.pdf).

Berkes, F., 2004. Re-thinking community based conservation. Cons Bio 18, 621-630.

Besner, M.-C., Prevost, M., Regli, S., 2011. Assessing the public health risk of microbial intrusion events in distribution systems: conceptual model, available data, and challenge. Water Res. 45 (3), 961-979. https://doi.org/10.1016/j.envsci.2018.02.014.

Biggs, N.L., Lloyd, E.K., Wilson, R.J., 1976. Graph Theory. Clarendon Press, Oxford, pp. 1736-1936.

Blackstock, K.L., Ingram, J., Burton, R., Brown, K.M., Slee, B., 2010. Understanding and influencing behavior change by farmers to improve water quality. Integr. Water Agric. Manag. Under Climate Change. 408 (23), 5631-5638. https://doi.org/ 10.1016/j.scitotenv.2009.04.029.

Borisova, T., Rocevskis, L., Jennison, K., 2012. Stakeholder analysis of a collaborative watershed management process: a Florida case study. Journal of the America Water Recourses Association 48 (2), 277-296. 
Bruns, A., 2012. How long is a tweet? Mapping dynamic conversation networks on twitter using gawk and gephi. J. Information, Communication \& Society 15, 1323-1351. https://doi.org/10.1080/1369118X.2011.635214

Cascetta, E., Carteni, A., Pagliara, F., Montanino, M., 2015. A new look at planning and designing transportation systems: a decision-making model based on cognitive rationality, stakeholder engagement and quantitative methods. Transp. Policy 38, 27-39. https://doi.org/10.1016/j.tranpol.2014.11.005.

Chopin, P., Guinde, L., Causeret, F., Bergkvist, G., Blazy, J.-M., 2019. Integrating stakeholder preferences into assessment of scenarios for electricity production from locally produced biomass on a small island. Renew. Energy 131, 128-136. https://doi.org/ 10.1016/j.renene.2018.06.031.

Cumming, G.S., Alcamo, J., Sala, O., Swart, R., Bennett, E.M., Zurek, M., 2005. Are existing global scenarios consistent with ecological feedbacks? Ecosystems 8, 143-152. https://doi.org/10.1007/s10021-004-0075-1.

Dadaser, F., Özesmi, U., 2001. Tuzla golu ekosistemi icin katilimci yonetim plani yontemi: bulanik biliseel haritalama yaklasimi (Participatory management plan for Tuzla Lake ecosystem: a fuzzy cognitive mapping approach). Proceedings of the IV National Environmental Engineering Congress, Mersin, Turkey, 7-10 November 2001, pp. 25-34.

Dadaser, F., Özesmi, U., 2002. Stakeholder analysis for Sultan Marshes ecosystem: a fuzzy cognitive approach for conservation of ecosystems. EPMR2002, Environmental Problems of the Mediterranean Region, Nicosia, North Cyprus. 12-15 April 2002.

Dahik, C., Crespo, P., Stimm, B., Murtinho, F., Weber, M., Hildebrandt, P., 2018. Contrasting stakeholders' perceptions of pine in the Paramo ecosystems of Ecuador. Sustainability 10, 1707. https://doi.org/10.3390/su10061707.

Daly, E.R., Roy, S.J., Blaney, D.D., Manning, J.S., Hill, V.R., Xiao, L., Stull, J.W., 2010. Outbreak of giardiasis associated with a community drinking-water source. J. Epidemiol. Infect 138, 491-500. https://doi.org/10.1017/S0950268809990744.

Darke, P., Shanks, G., 1996. Stakeholder viewpoints in requirements definition: a framework for understanding viewpoint development approaches. Requir. Eng. 1, 88-105. https://doi.org/10.1007/BF01235904.

Eliasson, J., 2014. The rising pressure of global water shortages. J. Sci. Commun. 517 (6). https://doi.org/10.1038/517006a.

Fenton, O., Mellander, P.-E., Daly, K., Wall, D.P., Jahangir, M.M.R., Jordan, P., Hennessey, D., Huebsch, M., Blum, P., Vero, S., Richards, K.G., 2017. Integrated assessment of agricultural nutrient pressures and legacies in karst landscapes. Agriculture Ecosystems and Environment 239, 246-256. https://doi.org/10.1016/j.agee.2017.01.014.

Flores, C., Vikolainen, V., Bressers, H., 2016. Water governance decentralisation and river basin management reforms in hierarchal systems: do they work for water treatment policy in Mexico's Tlaxcala Atoyac Sub-Basin. Water. 8, 210. https://doi.org/10.3390/ w8050210.

Foster, N., Collins, K., Ison, R., Blackmore, C., 2016. Water governance in England: improving understandings and practices through systematic co-inquiry. Water., 78-540 https://doi.org/10.3390/w8110540.

Gray, S., Chan, A., Clark, D., Jordan, R., 2012. Modelling the integration of stakeholder knowledge in social ecological decision making: benefits and limitations to knowledge diversity. Ecol. Model. 229, 88.96. https://doi.org/10.1016/j. ecolmodel.2011.09.011.

Gregory, R., Keeney, R.L., 1994. Creating policy alternatives using stakeholder values. Manag. Sci. 40, 1035-1048. https://doi.org/10.1287/mnsc.40.8.1035.

Groumpus, G., 2017. Why model complex dynamic systems using fuzzy cognitive maps? Robot Autom. Eng. J. 1 (3). https://doi.org/10.19080/RAEJ.2017.01.555563.

Gundry, S.W., Wright, J.A., Conroy, R., Du Preez, M., Genthe, B., Moyo, S., Mutisi, C., Ndamba, J., Potgieter, N., 2006. Contamination of drinking water between source and point-of-use in rural households of South Africa and Zimbabwe: implications for monitoring the Millennium Development Goal for water. J. Water Practice \& Technology 1, 2. https://doi.org/10.2166/WPT.2006032.

Harary, F., Norman, R.Z., Cartwright, D., 1965. Structural Models: An Introduction to the Theory of Directed Graphs. John Wiley \& Sons, New York (415 pp).

Harisha, R.S., Hosamani, K.M., Keri, R.S., Nataraj, S.J., Aminabhavi, T.M., 2010. Arsenic removal from drinking water using thin film composite nanofiltration membrane. J. Desalination. 252, 75-80. https://doi.org/10.1016/j.desal.2009.10.022.

Heymann, S., Le Grand, B., 2013. Visual analysis of complex networks of business intelligence with gephi. 17th International Conference on Information Visualization. London, UK. https://doi.org/10.1109/IV.2013.39.

Hjortsø, C.N., 2004. Enhancing public participation in natural resource management using Soft OR-an application of strategic option development and analysis in tactical forest planning. Eur. J. Operation. Res. 152, 667-683. https://doi.org/10.1016/S0377-2217 (03)00065-1.

Hyland, J., Heanue, K., McKillop, J., Micha, E., 2018a. Factors influencing dairy farmers' adoption of best management grazing practices. Land Use Policy 78, 562-571. https://doi.org/10.1016/j.landusepol.2018.07.006.

Hyland, J., Heanue, K., McKillop, J., Micha, E., 2018b. Factors underlaying farmers' intentions to adopt best practices: the case of paddock based grazing systems. Agric. Syst. 162, 97-106. https://doi.org/10.1016/j.agsy.2018.01.023.

Jacomy, M., Venturini, T., Heymann, S., Bastian, M., 2014. ForceAtlas2, a continuous graph layout algorithm for handy network visualization designed for the Gephi software. J. PLOS ONE 9 (6). https://doi.org/10.1371/journal.pone.0098679.

Jaramillo, M., O'Shea, E., 2019. Analytical methods for assessment of cyanotoxin contamination in drinking water sources. Current Opinion in Environmental Science and Health 7, 45-51. https://doi.org/10.1016/j.coesh.2018.10.003.

Jetter, J., Kok, K., 2014. Fuzze Cognitive Maps for future studies- a methodological assessment of concepts and methods. Futures 61, 45-57. https://doi.org/10.1016/j. futures.2014.05.002.

Jimenes, A., Saikia, P., Gine, R., Avello, P., Letten, J., Lymer, B., Schneider, K., Ward, R., 2020. Unpacking water governance: a framework for practitioners. Water 12, 827. https:// doi.org/10.3390/w12030827.
Juntunen, J.K., Halme, M., Korsunova, A., Rajala, R., 2018. Strategies for integrating stakeholders into sustainability innovation: a configurational perspective. J. Prod. Innov. Manag. 36 (3), 331-355. https://doi.org/10.1111/jpim.12481.

Kabunzana, N., Simatele, D., 2017. Sustainable solid waste management in sub-Saharan African cities: application of system thinking and system dynamic as methodological imperatives in Kinshasa, the Democratic Republic of Congo. Local Environ. 23 (2), 220-238. https://doi.org/10.1080/13549839.2017.1399996.

Kafetzis, A., McRoberts, N., Mouratiadou, I. (Eds.), 2010. Using Fuzzy Cognitive Maps to Support the Analysis of Stakeholders' Views of Water Recourse Use and Water Quality policy. Springer, pp. 2-29.

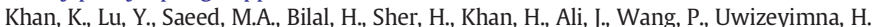
Baninla, Y., Li, Q., Liu, Z., Nawab, W., Zhou, Y., Su, C., L, R., 2018. Prevalent faecal contamination in drinking water resources and potential health risks in Swat, Pakistan. J. Environ. Sci. 72, 1-12. https://doi.org/10.1016/j.jes.2017.12.008.

Kirchhoff, C., Dilling, L., 2016. The role of U.S. states in facilitating effective water governance under stress and change. Water Resource Res 52, 2951-2964. https://doi.org/ 10.1002/2015WR018431.

Kok, K., 2009. The potential of Fuzzy Cognitive Maps for semi-quantitative scenario development, with an example from Brazil. Glob. Environ. Chang. 19 (1), 122-133. https:// doi.org/10.1016/j.gloenvcha.2008.08.003.

Kontogianni, A.-D., Papageorgiou, E.-I., Tourkolias, C., 2012. How to do percieve environmental change? Fuzzy cognitive mapping informing stakeholder analysis for environmental policy making and non-market valuation. Appl. Soft Comput. 12, 3725-3735. https://doi.org/10.1016/j.asoc.2012.05.003.

Kosko, B., 1986. Fuzzy cognitive maps. Int. J. Man-Machine Stud. (1), 65-75.

Kosko, B., 1987. Adaptive inference in fuzzy knowledge networks. Proceedings of the First IEEE International Conference on Neural Networks (ICNN-86), San Diego, California, pp. 261-268.

Lai, W.-P., Lin, Y.-C., Wang, Y.-H., Guo, Y.-L., Lin, Y.-C., 2018. Occurrence of emerging contaminants in aquaculture waters: cross-contamination between aquaculture systems and surrounding waters. Water Air Soil Pollut. 249. https://doi.org/10.1007/s11270018-3901-3.

Lou, Y., Guo, W., NGO, H., DucNghiem, L., Hai, F., Zhang, J., Liang, S., Wang, X., 2014. A review on the occurrence of micropollutants in the aquatic environment and their fate and removal during wastewater treatment. Sci. Total Environ. 473-473, 619-641. https://doi.org/10.1016/j.scitotenv.2013.12.065.

Lynam, T., De Jong, W., Sheil, D., Kusumanto, T., Evans, K., 2007. A review of tools for incorporating community knowledge, preferences, and values into decision making in natural resources management. Ecol. Soc. 12 (1), 5. http://www. ecologyandsociety.org/vol12/iss1/art5/.

Lyon, W., 2010. Water Governance in the United States- A Ship With Neither a Captain nor a Rudder. Discussion of Water Governance at 5th World Water Forum. https:// doi.org/10.1109/IV.2013.39.

Machado, C., Grassi, M.T., Vidal, C., Pescara, I.C., Jardim, W., Fernandes, A., Sodre, F., Almeida, F., Santana, J., Canela, M.C., Nunes, C.R.O., Bichinho, K., Severo, F., 2016. A preliminary nationwide survey of the presence of emerging contaminants in drinking and source waters in Brazil. Sci. Total Environ. 572, 138-146. https://doi.org/10.1016/ j.scitotenv.2016.07.210.

Martin, E.G., Giordano, R., Pagano, A., Van Der Keur, P., Costa, M.M., 2020. Using a system thinking approach to assess the contribution of nature-based solutions to sustainable development goals. Sci. Total Environ. 738, 139693. https://doi.org/10.1016/j. scitotenv.2020.139693.

McGrory, E.R., Brown, C., Bargary, N., Williams, N.H., Mannix, A., Zhang, C., Henry, C., Daly, E., Nicholas, S., Petrunic, B.M., Lee, M., Morrison, L., 2017. Arsenic contamination of drinking water in Ireland: a spatial analysis of occurrence and potential risk. Sci. Total Environ. 579, 1863-1875. https://doi.org/10.1016/j.scitotenv.2016.11.171.

Micha, E., Fenton, O., Daly, K., Kakonyi, G., Ezzati, G., Moloney, T., Thornton, S., 2020. The complex pathways towards farm-level sustainable intensification: an exploratory network analysis of stakeholders' knowledge and perception. Sustainability 12, 2578. https://doi.org/10.3390/su12072578.

Miller, K.A., 2011. Grappling with uncertainty: water planning and policy in a changing climate. Environ. Energy Law Policy. 5 (2), 395-416. http://www.law.uh.edu/eelpj/ publications/5-2/06Miller.

Morton, P.A., Fennel, C., Cassidy, R., Doody, D., Fenton, O., Mellander, P.-E., Jordan, P., 2019. A review of the pesticide MCPA in the land-water environment and emerging research needs. Wiley Wires water 1-16.

Naidu, R., Espana, V.-A.-A., Liu, Y., Jit, Y.J., 2016. Emerging contaminants in the environment: risk-based analysis for better management. Chemosphere 154, 350-357. https://doi.org/10.1016/j.chemosphere.2016.03.068.

Nelson, R., Howden, M., Smith, M.S., 2008. Using Adaptative governance to rethink the way science supports Austrian drought policy. Environmental Science Policy 11, 588-601. https://doi.org/10.1016/j.envsci.2008.06.005.

Okumah, M., Yeboah, A., 2020. Exploring stakeholders' perceptions of the quality and governance of water resources in the Wenchi municipality. J. Environ. Plan. Manag. 63 (8), 1375-1403. https://doi.org/10.1080/9640568.2019.1663724.

Ozesmi, U., 1999. Modelling ecosystems from local perspectives: fuzzy cognitive maps of the Kizilirmak Delta wetlands in Turkey. 1999 World Conference on Natural Resource Modelling 23-25 June 1999, Halifax, Nova Scotia, Canada.

Ozesmi, U., Ozesmi, S., 2003. A participatory approach to ecosystem conservation: fuzzy cognitive maps and stakeholders group analysis in Uluabat lake, Turkey. Environ. Manag. 31 (4), 518-531. https://doi.org/10.1007/s00267-002-2841-1.

Ozesmi, U., Ozesmi, S., 2004. Ecological models based on people's knowledge: a multistep fuzzy cognitive mapping approach. Ecol. Model. 176, 43-64. https://doi.org/ 10.1016/j.ecolmodel.2013.10.027.

Panikkar, B., Lemmond, B., Allen, L., DiPirro, C., Kasper, S., 2019. Making the invisible visible: results of a community-led health survey following PFAS contamination of 
drinking water in Merrimack, New Hampshire. Environ. Health 18, 79. https://doi. org/10.1186/s12940-019-0513-3.

Papageorgiou, E., Kontogianni, A., 2012. Using fuzzy cognitive mapping in environmental decision making and management: A methodological premier and an application. In: S. Young, S., E. Silvern, S. (Eds.), International Perspectives on Global Environment Change. In-Tech., Rijeka, pp. 427-445.

Puccia, C.J., 1983. Qualitative models for east coast benthos. In: Lauenroth, W.K., Skogerboe, G.V., Flug, M. (Eds.), Analysis of Ecological Systems: State-of-the-art in Ecological Modelling. Elsevier, Amsterdam, pp. 719-724.

Radomski, P.J., Goeman, T.J., 1996. Decision making and modeling in freshwater sportfisheries management. Fisheries 21, 14-21. https://doi.org/10.1577/1548-8446 (1996) $021<0014$ : DMAMIF>2.0.CO;2.

Reimann, S., 1998. On the design of artificial auto-associative neural networks. Neural Netw. 11, 611-621.

Rufener, S. Mausezahl, D. Mosler, H.-J. Weingartner, R, 2010. Quality of drinking water at source and point of consumption-drinking cup as a high potential recontamination risk: a field study in Bolivia. J. Health population and Nutrition. 28 (1), 34-41. https:// doi.org/10.3329/jhpn.v28i1.4521.

Sandell, K., 1996. Sustainability in theory and practice: a conceptual framework of ecostrategies and a case study of low-resource agriculture in the dry zone of Sri lanka. In: Hjort-af-Ornãs, A. (Ed.), Approaching Nature from Local Communities: Security Perceived and Achieved. Linköping University, Linköping, Sweden, pp. 163-197.

Schmoll, O., Howard, G., Chilton, J., Chorus, I., 2006. Protecting Groundwater for Health. fourth ed. WHO and IWA Publishing, CHF.
Schutz, K.E., Huddart, F.J., Cox, N.R., 2019. Manure contamination of drinking water influences dairy cattle water intake and preference. Appl. Anim. Behav. Sci. 17, 16-20. https://doi.org/10.1016/j.applanim.2019.05.005.

Suprun, E., Sahin, O., Sewart, R.-A., Panuawatwanich, K., Shcherbachenko, Y., 2018. An integrated participatory systems modelling approach: application to construction innovation. Systems 6, 33. https://doi.org/10.3390/systems6030033.

Ulrich, W., Reynolds, M., 2010. Critical systems heuristics. In: Reynolds, M., Holwell, S. (Eds.), Systems Approaches to Managing Change: A Practical Guide. Springer-Verlag, London, UK, pp. 243-292.

Voinnov, A., Bousquet, F., 2010. Modelling with stakeholders. Environ. Model Softw. 25, 1268-1281. https://doi.org/10.1016/j.envsoft.2010.03.007.

Voinnov, A., Kolagani, N., McCall, M., Glynn, Pierre, Kragt, M., Ostermann, F., Pierce, S., Ramu, P., 2016. Modelling with stakeholders-next genreation. Environ. Model Softw. 77, 196-220. https://doi.org/10.1016/j.envsoft.2015.11.016.

Wiek, A., Larson, K., 2012. Water, people, and sustainability- a systems framework for analyzing and assessing water governance regimes. J. Water. Resour. Manage 26 3153-3171. https://loi.org/10.1007/s11269-012-0065-6.

Yalçın, N., Seçme, G., 2001. Bulanik Bilissel Haritama Teknigi Ile Kayseri Sanayiinin Problemlerinin Tespit Edilmesi ve Gelisme Imkanlarinin Gosterilmesi (Fuzzy Cognitive Mapping Technique to Examine the Problems and Development Opportunities for Kayseri Industry). Graduation thesis. Erciyes University Industrial Engineering Department. 